\title{
Hubungan Lama Duduk dan Sikap Duduk Terhadap Keluhan Nyeri Punggung Bawah Pada Penjahit Rumahan Di Kecamatan Tasikmadu
}

\author{
Corelations Of Sitting Duration And The Attitude Of The Sitting To Low Back Pain Complaints \\ of Tailors Home At Subdistrict Tasikmadu
}

Nur Rahmat ${ }^{1}$, Prasetyo Catur Utomo ${ }^{1}$, Esa Ridho Sambada ${ }^{1}$, Esti Novi Andyarini ${ }^{2}$

${ }^{1}$ Jurusan Ortotik Prostetik, Poltekkes Kemenkes Surakarta, ${ }^{2}$ UIN Sunan Ampel Suarabaya nurrachmat@gmail.com

DOI: http://doi.org/10.29080/jhsp.v3i2.204

Received: Mei 2019, Accepted: Juni 2019, Published : September 2019

\section{Kata Kunci}

Lama Duduk,

Sikap Duduk,

Nyeri

Punggung

Bawah,

Penjahit.

\begin{abstract}
Abstrak
Banyak warga Kecamatan Tasikmadu yang bekerja menjahit di rumah. Posisi kerja menjahit mengharuskan penjahit untuk duduk lama menyelesaikan pekerjaannya. Sikap duduk saat bekerja menjahit dan lama waktu saat duduk menjahit tersebut berhubungan dengan nyeri punggung bagian bawah yang dirasakan oleh para penjahit. Nyeri Punggung Bawah (NPB) merupakan salah satu gangguan musculoskeletal yang disebabkan oleh aktivitas tubuh yang kurang baik. Pekerja perlu diberikan istirahat aktif untuk dapat menghindari pekerjaan yang monoton dalam jangka waktu lama dan relaksasi untuk mengendorkan ketegangan saraf serta otot akibat kerja. Penelitian ini bertujuan untuk mengetahui hubungan nyeri punggung bawah dengan sikap dan lama penjahit duduk bekerja. Metode penelitian analitik observasional dengan studi cross sectional. Subjek yang digunakan adalah penjahit rumahan yang berada di Kecamatan Tasikmadu. Hasil: Nilai lama duduk ( $p=0,000$ ) sedangkan sikap duduk $(0,038)$ yang berarti terdapat hubungan dengan adanya nyeri punggung bawah penjahit. Dari kedua hubungan diatas dapat di katakan bahwa lebih berhubungan lama duduk $(0,713)$ dari pada sikap duduk $(0,334)$ terhadap keluhan nyeri punggung bawah. Semakin lama ataupun semakin salah dalam melakukan aktifitas menjahit baik waktu menjahit maupun sikap dalam menjahit maka akan semakin mempengaruhi keluhan nyeri punggung bawah.
\end{abstract}

\section{Keywords}

Sitting

Duration,

Sitting Attitude,

Low Back Pain,

Tailors.

\begin{abstract}
Many residents of Tasikmadu Sub-district work sewing at home. Work position is complete for scheduling is complete. The sitting posture while working sewing and the length of time sitting related to this work are given with the back of the part received by the tailors. Low Back Pain (LPB) is one of the musculoskeletal disorders caused by poor body activity. Workers need to be given active rest to be able to avoid monotonous work for a long time and, and relaxation to relax nerve and muscle tension due to work. This study aims to determine the relationship between low back pain with the attitude and length of tailor sitting to work. Method and Subject: Type of research is an observational analytic with cross sectional study. The subject used is a home tailor in Tasikmadu District. Results: It was found that sitting time $(p=0,000)$ and sitting attitude $(0,038)$ had a relationship with the incidence of NPB. From the two relations above, it can be said that the duration of sitting (0.713) is more related thanattitude of sitting (0.334) against of low back pain complaints. More longer or more wrong in carrying out sewing activities both sewing time and sewing attitude will increasingly affect complaints of lower back pain.
\end{abstract}




\section{Pendahuluan}

Nyeri punggung bagian bawah adalah gangguan nyeri pada otot yang sering terjadi pada saat bekerja dengan posisi duduk yang kurang tepat (1). Nyeri Punggung bagian bawah merupakan rangking keenam dari 291 penyakit yang menyebabkan disabilitas tahunan (2). Masyarakat usia lebih dari 65 tahun di Jawa Tengah yang mengalami nyeri pungggung sekitar 18,2\% Laki-laki dan 13,6\% Perempuan. Terapat sekitar $3-17 \%$ orang yang mengalami nyeri punggung bawah yang periksa ke rumah sakit di Indonesia (3). Duduk lama dan sikap duduk yang kurang tepat maupun aktifitas yang terlalu banyak adalah beberapa faktor penyebab nyeri punggung bawah (4). Duduk di kursi kurang sesuai, aktivitas yang dilakukan terlalu lama dan beberapa penyakit adalah faktor penyebab nyeri punggung bawah (5)

Pekerjaan menjahit sering menyebabkan gangguan otot, yaitu nyeri pada punggung bagian bawah. Bekerja sebagai penjahit pada usaha konveksi mengharuskan seseorang untuk duduk dengan waktu yang cukup lama dan dengan posisi yang kurang tepat dengan gerakan membungkuk dan mengangkat beban yang kurang sesuai yang menyebabkan nyeri punggung bawah (6)

Berdasarkan The Global Burden of Disease 2010 Study, dari 291 penyakit yang diteliti, NPB merupakan penyumbang terbesar kecacatan global, yang diukur melalui years lived with disability (YLD), serta menduduki peringkat yang keenam dari total beban secara keseluruhan, yang diukur dengan the disability-adjusted life year (DALY). Pengukuran DALY adalah metrik standar untuk mengukur beban yang dihitung dengan menggabungkan years of life lost (YLL) dan years lived with disability (YLD) (7). Berdasarkan profil Departemen Kesehatan tahun 2005, sebanyak 40,5\% penyakit disebabkan oleh pekerjaannya. Studi 9.482 pekerja di 12 Kabupaten/kota di Indonesia sebagian besar berupa penyakit NPB $(16 \%)$, kardiovaskuler $(8 \%)$, gangguan saraf $(6 \%)$, gangguan pernafasan $(3 \%)$,dan penyakit THT $(1,5 \%)$ (8).

Data epidemiologi mengenai NPB yang di peroleh di Indonesia belum ada, namun diperkirakan $40 \%$ penduduk pulau Jawa Tengah mengalami sakit pada punggung yaitu lansia lebih dari 65 tahun, angka kejadian pada laki-laki 18,2\% dan pada wanita 13,6\%. Insiden berdasarkan kunjungan pasien ke beberapa rumah sakit di Indonesia berkisar antara 3-17\%. NPB dapat dialami siapa saja, pada umur berapa saja. Namun demikian keluhan NPB jarang dijumpai pada kelompok umur 0-10 tahun, hal ini mungkin berhubungan dengan beberapa faktor etiologi tertentu yang sering dijumpai pada usia yang lebih tua (9).

Menurut World Health Organization (WHO) , 2-5\% dari karyawan di negara industri tiap tahun mengalami nyeri punggung bawah, dan 15\% dari karyawan terbenut merupakan pekerja angkat barang, kuli, penjahit, operator komputer, serta pekerjaan yang berhubungan dengan masalah punggung (10).

Penyebab nyeri punggung bawah yang paling sering adalah duduk terlalu lama, sikap duduk yang salah, dan aktivitas yang berlebihan. Dari hasil penelitian tersebut didapatkan hubungan lama dan posisi duduk dengan kejadian nyeri punggung bawah (11).

Adapun faktor-faktor yang berhubungan dengan keluhan nyeri punggung bawah diantaranya adalah, berdiri atau membungkuk dalam waktu yang lama, duduk dikursi yang tidak sesuai, mengemudi dalam waktu yang lama, postur tubuh yang buruk, kurang berolahraga, kegemukan, hamil, mengangkat, menjinjing, mendorong, atau menarik beban yang terlalu berat. Selain faktor diatas, faktor lain yang berhubungan dengan keluhan nyeri punggung bawah adalah cedera, penyakit peradangan, kanker, dan osteoporosis (12).

Sebagai contoh pekerjaan yang dapat menyebabkan gangguan muskuloskeletal adalah menjahit. Di Indonesia, menjahit merupakan pekerjaan yang telah ditekuni baik individu maupun usaha konveksi. Dalam melakukan pekerjaan, pekerja beresiko mendapat kecelakaan ataupun penyakit akibat kerja. Hal ini dapat terjadi karena pekerja sering mengalami posisi duduk dan lama duduk yang tidak sesuai sehingga terjadi keadaan postur yang kaku dan beban otot yang statis. Aktivitas yang terlalu menggunakan gerak ke depan maupun membungkuk, mengangkat beban berat secara tidak tepat, maupun bekerja dengan posisi duduk dalam jangka waktu yang lama kemungkinan merupakan faktor yang dapat menyebabkan nyeri pada bagian anggota badan, punggung, lengan, bagian persendian, dan jaringan otot lainnya (13).

Pekerjaan menjahit di lakukan dalam jangka waktu yang lama dan dalam posisi yang sama setiap harinya sehingga menyebabkan nyeri punggung bawah. Hal ini menjadi menarik untuk diteliti tentang adanya hubungan posisi duduk dan lama duduk terhadap kejadian NPB pada penjahit rumahan di Kecamatan Tasikmadu.

\section{Metode Penelitian}

Penelitian analitik observasional memakai desain studi cross sectional ini dilaksanakan di Kecamatan Tasikmadu, Kabupaten Karanganyar, Provinsi Jawa Tengah, Indonesia pada bualan Januari - Mei 2019. variabel independen dan variabel dependen diukur pada waktu yang sama. Penelitian ini bertujuan untuk mengetahui hubungan antara lama duduk dan sikap duduk terhadap keluhan Nyeri Punggung Bawah pada penjahit rumahan di Kecamatan Tasikmadu.Populasi penelitian meliputi penjahit rumahan yang berada di Kecamatan Tasikmadu.Peneliti akan mengambil seluruh sample penjahit yang yang ada di kecamatan Tasikmadu yaitu 39 sample yaitu total sampling. Kriteria inklusi adalah penjahit rumahan yang bekerja 
penuh waktu. Kriteria eksklusi adalah penjahit yang sudah mempunyai penyakit patologis pada punggung. Pengumpulan data dilakukan secara langsung dengan menggunakan Stopwatch, RULA (Rapid Upper Limb Assessment), NRS (Numeric Rating Scale. Analisa yang digunakan menggunakan Bivariat dengan Uji Hipotesis Spearmen-Rank. Sebelum mengisi instrumen, responden diminta kesediannya mengisi inform consent. Lama duduk diukur menggunakan Stopwatch Digital. Stopwatch akan di tekan jika subjek duduk hanya pada saat bekerja menjahit lalu Stopwatch akan di hentikan pada saat pasien intirahat dan dinyalakan lagi jika subjek kembali bekerja. Lalu peneliti mengisi lembar pengisian dengan ketelitian 0,01 detik. Setelah dilakukan penghitungan lama duduk didapatkan hasil Grade Score yaitu $0=$ Jika lama duduk $\geq 4$ Jam, dan $1=$ Jika $<4$ Jam.

Sikap duduk menggunakan Rapid Upper Limb Assessment atau RULA, kamera dan busur. Dengan cara pasien diminta untuk bekerja seperti biasanya, lalu kita foto sikap duduk subjek. Setelah pengambilan gambar maka peneliti akan mengukur derajad sikap duduk pasien dengan menggunakan aplikasi ergonomi di laptop. Lalu peneliti akan menerjemahkan dan memasukkan angka tersebut ke dalam lembar RULA. Setelah memasukkan hasil ke lembar RULA, maka akan didapatkan hasil akhir 1 sampai 7 ( baik sampai sangat buruk ). Pengukuran RULA dilakukan pengulangan 3 kali.

Pengukuran nyeri pada penelitian ini menggunakan Numeric Rating Scale (NRS). Disini menggunakan Numeric Rating Scale dikarenakan cara pengukuran ini hanya untuk mengukur intensitas nyeri yang dirasakan subjek. Terdiri dari skala horizontal yang dibagi secara rata menjadi 10 segmen dengan nomor 0 sampai 10. Pasien diberi pengertian yang menyatakan bahwa angka 0 bermakna intensitas nyeri yang minimal (tidak ada nyeri sama sekali) dan angka 10 bermakna nyeri yang sangat (nyeri paling parah yang dapat mereka bayangkan). Pasien kemudian dimintai untuk menandai angka yang menurut mereka paling tepat dalam mendeskripsikan tingkat nyeri yang dapat mereka rasakan pada suatu waktu.

\section{Hasil Penelitian}

\section{Karakteristik Responden}

Karakteristik responden dalam penelitian ini dapat dilihat pada table 1.

Tabel 1 Karakteristik Responden

\begin{tabular}{lrr}
\hline Karakteristik & frekuensi & Persentase \\
\hline Jenis Kelamin & & \\
Laki-laki & 11 & $28,20 \%$ \\
Perempuan & 28 & $71,80 \%$ \\
Usia & & \\
$20-29$ & 1 & $2,60 \%$ \\
$30-39$ & 5 & $12,80 \%$ \\
$40-49$ & 11 & $28,20 \%$ \\
$50-59$ & 14 & $35,90 \%$ \\
Tinggi Badan & & \\
$140-149$ & 7 & $17,90 \%$ \\
$150-159$ & 20 & $69,20 \%$ \\
$160-169$ & 9 & $23,10 \%$ \\
$170-179$ & 3 & $7,70 \%$ \\
Berat Badan & & \\
$30-39$ & 1 & $2,60 \%$ \\
$40-49$ & 7 & $17,90 \%$ \\
$50-59$ & 10 & $25,60 \%$ \\
$60-69$ & 14 & $35,90 \%$ \\
$70-79$ & 2 & $5,10 \%$ \\
$80-89$ & 5 & $12,80 \%$ \\
Pendidikan Terakhir & & \\
SD & 8 & $20,50 \%$ \\
SMP & 19 & $48,70 \%$ \\
SMA & 9 & $23,10 \%$ \\
PT & 3 & $7,70 \%$ \\
\hline & &
\end{tabular}




\section{Lama Duduk}

Distribusi Responden Berdasarkan Lama Duduk dapat dilihat pada Tabel 2.

Tabel 2. Distribusi Responden Berdasarkan Lama Duduk

\begin{tabular}{ccc}
\hline Lama Duduk & Frekuensi & Persentase \\
\hline Lama Duduk $\geq 4$ Jam & 22 & $56,4 \%$ \\
Lama Duduk < 4 Jam & 17 & $43,6 \%$ \\
Total & $\mathbf{3 9}$ & $\mathbf{1 0 0 \%}$ \\
\hline
\end{tabular}

\section{Keluhan Nyeri Punggung Bawah}

Distribusi Responden Berdasarkan Keluhan Nyeri Punggung Bawah yang diukur menggunakan Numeric Rating Scale (NRS) dapat dilihat pada Tabel 3.

Tabel 3. Distribusi Responden Berdasarkan Keluhan Nyeri Punggung Bawah

\begin{tabular}{ccc}
\hline Keluhan NPB & Frequency & Percent \\
\hline 0 & 12 & $30,8 \%$ \\
1 & 1 & $2,6 \%$ \\
2 & 2 & $5,1 \%$ \\
3 & 8 & $20,5 \%$ \\
4 & 4 & $10,3 \%$ \\
5 & 5 & $12,8 \%$ \\
6 & 4 & $10,3 \%$ \\
7 & 2 & $5,1 \%$ \\
8 & 1 & $2,6 \%$ \\
Total & $\mathbf{3 9}$ & $\mathbf{1 0 0 , 0} \%$ \\
\hline
\end{tabular}

\section{Sikap Duduk}

Distribusi Responden Berdasarkan Sikap Duduk dapat dilihat pada Tabel 4.

Tabel 4. Distribusi Responden Berdasarkan Sikap Duduk

\begin{tabular}{ccc}
\hline Sikap Duduk & Frekuensi & Persentase \\
\hline Sangat Baik & 0 & $0 \%$ \\
Baik & 16 & $41 \%$ \\
Buruk & 18 & $46,2 \%$ \\
Sangat Buruk & 5 & $12,8 \%$ \\
Total & $\mathbf{3 9}$ & $\mathbf{1 0 0} \%$ \\
\hline
\end{tabular}

\section{Hubungan Lama Duduk Terhadap Keluhan Nyeri Punggung Bawah}

Hubungan Lama Duduk Terhadap Keluhan Nyeri Punggung Bawah dapat dilihat pada tabel 5.

Tabel 5. Hubungan Lama Duduk Terhadap Keluhan Nyeri Punggung Bawah

\begin{tabular}{cccc}
\hline \multicolumn{2}{c}{ CORELATION } & \multicolumn{2}{c}{ NYERI } \\
PUNGGUNG \\
BAWAH
\end{tabular}

Dari hasil tabel 5. menunjukan hasil uji sprearman yang dilakukan terhadap untuk hasil signifikansinya dari lama duduk terhadap keluhan nyeri punggung bawah dengan nyeri punggung bawah maka didapatkan signifikansi sebesar 0,00 dari kedua hasil tersebut berarti signifikansinya kurang dari 0,05, sehingga terdapat hubungan antara lama duduk penjahit dengan nyeri punggung bawah.

Tingkat hubungan kuat ditunjukkan dengan nilai Correlation Coefficient-nya 0,713 (71,3\%). Lalu untuk arah hubungan di dalam penelitian ini yaitu positif. Maksutnya adalah jika semakin lama ataupun semakin salah dalam melakukan aktifitas menjahit maka akan semakin mempengaruhi keluhan nyeri punggung bawah terbukti dengan Correlation Coefficient yang berupa angka positif yaitu 0,713. 


\section{Hubungan Sikap Duduk Terhadap Keluhan Nyeri Punggung Bawah}

Hubungan Sikap Duduk Terhadap Keluhan Nyeri Punggung Bawah dapat dilihat pada tabel 6.

Tabel 6. Hubungan Sikap Duduk Terhadap Keluhan Nyeri Punggung Bawah

\begin{tabular}{cccc}
\hline \multicolumn{2}{c}{ CORELATION } & SIKAP & NYERI PUNGGUNG \\
& & DUDUK & BAWAH \\
\hline \multirow{2}{*}{ Sikap Duduk } & Correlation Coefficient & 1,000 &, $334^{*}$ \\
& Sig. (2-tailed) & N & 39 \\
Nyeri Punggung Bawah & Correlation Coefficient &, $334^{*}$ & 39 \\
& Sig. (2-tailed) &, 038 & 1,000 \\
\hline
\end{tabular}

Dari hasil tabel 6 menunjukan hasil uji sprearman dari sikap duduk dengan keluhan nyeri punggung bawah didapatkan signifikansi sebesar 0,38 dari kedua hasil tersebut berarti signifikansinya kurang dari 0,05, sehingga terdapat hubungan lama duduk penjahit dengan nyeri punggung bawah.

Tingkat hubungan rendah dengan nilai Correlation Coefficient-nya 0,334 (33,4\%). Lalu untuk arah hubungan di dalam penelitian ini yaitu positif. Maksudnya adalah jika semakin lama ataupun semakin salah dalam melakukan aktifitas menjahit maka akan semakin mempengaruhi nyeri punggung bawah terbukti dengan Correlation Coefficient yang berupa angka positif yaitu 0,334.

Dari kedua hubungan diatas dapat di katakan bahwa lebih berhubungan lama duduk dari pada sikap duduk terhadap keluhan nyeri punggung bawah sebesar 71,3\%. Dikarenakan nilai Correlation Coefficient nya lebih besar yaitu $0,713>0,334$.

\section{Pembahasan}

Pengambilan data dilakukan pada 39 orang penjahit rumahan sebagai sampel penelitian. Peneliti sebelumnya sudah bertemu dengan responden terlebih dahulu untuk menanyakan kesediaannya untuk dilakukannya penelitian. Pada saat pengambilan data, peneliti meminta bantuan untuk mengambil data lama duduk. Lalu menyebar ke tempat yang sudah ditentukan. Gambar 1 menunjukkan Pengambilan data Lama duduk menggunakan stopwatch. Sedangkan peneliti mengunjungi responden untuk melakukan pengambilan data sikap duduk pada saat menjahit dan menanyakan keluhan nyeri punggung bawah. Gambar 2 menunjukkan Sikap Duduk Penjahit.

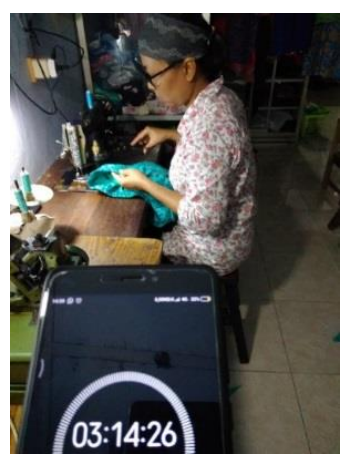

Gambar 1. Pengambilan data Lama duduk menggunakan stopwatch

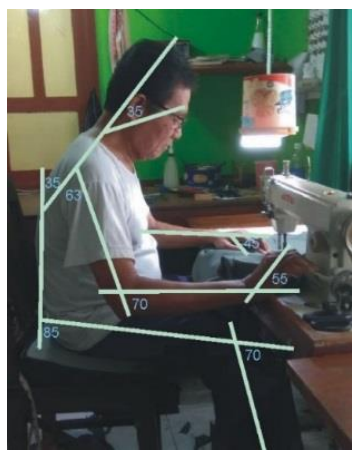

Gambar 2. Sikap Duduk Penjahit

Karakteristik responden berdasarkan usia yaitu dari 39 responden terdapat 1 responden $(2,6 \%)$ yang berusia antara 20-29 tahun, sebanyak 5 responden (12,8\%) yang berusia antara 30-39 tahun, 
sebanyak 11 responden $(28,2 \%)$ yang berusia antara 40-49 tahun, sebanyak 14 responden $(35,9 \%)$ yang berusia antara 50-59 tahun, dan 8 responden (20,5\%) yang berusia antara 60-69 tahun.

Karakteristik subjek berjenis kelamin laki-laki lebih banyak dari perempuan yaitu sebanyak 28 orang ( $71,8 \%$ ). Karakteristik berdasarkan tinggi badan sebanyak 7 responden $(17,9 \%)$ memiliki tinggi badan 140-149 cm, sebanyak $20(69,2 \%)$ responden memiliki tinggi badan 150-159 cm, sebanyak 9 responden $(23,1 \%)$ memiliki tinggi badan $160-169 \mathrm{~cm}$, lalu sebanyak 3 orang responden $(7,7 \%)$ memiliki tinggi badan $1170-179 \mathrm{~cm}$.

Karakteristik berdasarkan berat badan yaitu 1 responden $(2,6 \%)$ yang mempunyai berat badan antara 30-39 kg, sebanyak 7 responden (17,9\%) yang mempunyai berat antara 40-49 kg, sebanyak 10 responden (25,6\%) yang mempunyai berat antara 50-59 kg, sebanyak 14 responden (35,9\%) yang mempiunyai berat antara 60-69 kg, sebanyak 2 responden (5,1\%) yang mempunyai berat antara $70-79 \mathrm{~kg}$, serta 5 orang responden $(12,8)$ mempunyai berat badan antara 80-89 kg. Karakkteristik berdasar Pendidikan diketahui bahwa pendidikan terakhir SMP mempunyai frekuensi paling banyak yaitu 19 responden(48,7\%), lalu di urutan kedua SMA yaitu 9 responden $(23,1 \%)$, lalu SD sebanyak 8 responden (20,5\%), di urutan terakhir Perguruan Tinggi yaitu dengan jumlah 3 orang responden $(7,7 \%)$.

Sebagian besar responden memiliki lama duduk lebih dari 4 jam dan duduk dengan sikap yang kurang ergonomis disebabkan para pekerja dalam melakukan pekerjaannya di target oleh pelanggannya untuk jadi sehingga responden melakukan aktivitas pekerjaannya secara monoton dan tidak diselingi dengan istirahat. Dan hanya akan istirahat pada saat jam makan siang dan sholat ashar

Lama duduk juga dapat menimbulkan terjadinya spasme otot atau ketegangan pada daerah pantat. Pekerja perlu diberikan istirahat aktif untuk dapat menghindari pekerjaan yang monoton dalam jangka waktu lama, dan relaksasi untuk mengendorkan ketegangan saraf dan otot akibat kerja. Sehingga kejenuhan kerja dapat dikurangi, memulihkan kesegaran mental, dan akhirnya dapat meningkatkan produktivitas kerja. Selain itu dapat juga dilakukan perbaikan terhadap stasiun kerja para penjahit. Perbaikan stasiun kerja dapat menurunkan keluhan muskuloskeletal pada perajin ukir kayu (14).

Nyeri punggung tersebut dapat terjadi pada berbagai situasi kerja, tetapi risikonya lebih besar apabila duduk lama dalamposisi statis karena akan menyebabkan kontraksi otot yang terus menerus serta penyempitan pembuluh darah. Pada penyempitan pembuluh darah aliran darah terhambat dan terjadi iskemia, jaringan kekurangan oksigen dan nutrisi, sedangkan kontraksi otot yang lama akan menyebabkan penumpukan asam laktat, kedua hal tersebut menyebabkan nyeri (15).

Advances in industrial ergonomics and safety IV melaporkan tiga-perempat dari semua pekerja di negara industri mempunyai pekerjaan tetap yang mengharuskan duduk dalam waktu yang lama. Telah banyak penelitian yang mengidentifikasi faktor risiko pekerjaan yang terkait dengan kejadian nyeri punggung bawah, diantara faktor risiko yang diidentifikasi, duduk sering disebutkan sebagai faktor risiko dalam beberapa literature (16).

Lama duduk dapat berdiri sendiri sebagai faktor resiko yang signifikan untuk NPB, kecuali jika dikombinasikan dengan sikap duduk yang salah dan getaran pada tubuh maka mungkin akan meningkatkan resiko berkembangnya NPB. Namun oleh Diana Samara dikatakan bahwa lama duduk merupakan penyebab tersering timbulnya NPB dengan angka kejadian pada orang dewasa 39,7 - $60 \%$. NPB disebut berkaitan dengan duduk selama lebih dari 4 jam. Sejumlah penelitian lain juga menunjukkan keterkaitan antara lama duduk dengan NPB. Magora menemukan prevalensi NPB sebesar 12,6 \% pada orang yang sering bekerja duduk lebih dari 4 jam, 1,2 \% kadang-kadang duduk lebih dari 4 jam, dan 25,9 $\%$ jarang duduk dengan waktu kurang dari 2 jam. Penelitian yang dilakukan oleh Emami dkk juga menunjukkan NPB berkaitan dengan duduk selama lebih dari 4 jam, namun NPB tidak berkaitan dengan duduk selama kurang dari 1 jam per hari (17).

Terlalu lama duduk dan dengan posisi yang kurang tepat membuat orang capek dan kurang efisien bekerja. Posisi lordosis yaitu membungkuk dengan beban pada tulang belakang yang terlalu banyak merupakan gangguan otot utamanya otot perut dan otot punggung yang menjadi sebab nyeri punggung bawah (18).

Hasil penelitian dapat dilihat pada tabel 4.12 dan 4.13 didapatkan nilai significancy menunjukkan angka 0,00 dan $0,038(\mathrm{p}<0,05)$ maka dapat dinyatakan bahwa terdapat hubungan lama duduk dan sikap duduk terhadap nyeri punggung bawah pada penjahit rumahan di Kecamatan Tasikmadu. lama duduk lebih memiliki hubungan yang kuat dari pada sikap duduk terhadap keluhan nyeri punggung bawah. Dikarenakan nilai Correlation Coefficient nya lebih besar yaitu 0,713>0,334.

\section{Simpulan dan Saran}

Terdapat hubungan lama duduk dan sikap duduk terhadap keluhan nyeri punggung bawah pada penjahit rumahan di Kecamatan Tasikmadu yaitu pada uji spearman sebesar 0,000 dan 0,038. Tingkat hubungan antara lama duduk terhadap keluhan nyeri punggung bawah lebih rendah daripada sikap duduk terhadap keluhan nyeri punggung bawah. Dari kedua hubungan diatas dapat di katakan bahwa lebih berhubungan lama duduk dari pada sikap duduk terhadap keluhan nyeri punggung bawah. Dikarenakan 
nilai Correlation Coefficient nya lebih besar yaitu 0,713>0,334. Semakin lama ataupun semakin salah dalam melakukan aktifitas menjahit baik waktu menjahit maupun sikap dalam menjahit maka akan semakin mempengaruhi keluhan nyeri punggung bawah.

Penjahit disarankan untuk duduk pada saat bekerja jangan terlalu lama dengan waktu kurang dari 4 jam, Karena duduk lebih dari 4 jam perhari dapat menyebabkan keluhan nyeri punggung bawah. Sikap duduk Saat menjahit hendaknya disesuaikan dengan prinsip-prinsip ergonomi dan perlu diperhatikan postur tubuh dalam keadaan seimbang.

\section{Daftar Pustaka}

1. Pratiwi H, M. S, Y. K, B., Martini M. Beberapa Faktor Yang Berpengaruh Terhadap Keluhan. Dalam: Nyeri Punggung; Jurnal Promosi Kesehatan Indonesia. 2009.

2. Patrianingrum M, Oktaliansah E, Surahman E. Prevalensi dan Faktor Risiko Nyeri Punggung Bawah di Lingkungan. Jurnal Anestesi Perioperatif. 2015;hal:47-56.

3. Wulandari I. Hubungan Lama Dan Sikap Duduk Perkuliahan Terhadap Keluhan Nyeri Punggung Bawah Miogenik Pada Mahasiswa Di Universitas Muhammadiyah Surakarta. Jurnal Pena. 2010;hal.:29-37.

4. Safitri A.I., 2010; Hubungan Lama Posisi Duduk Terhadap Nyeri Punggung Bawah Pada Pegawai Rental Komputer di Kentingan Surakarta. Universitas Muhammadiyah Surakarta. Surakarta.

5. Ningsih WK. Keluhan Low Back Pain Pada Perawat Rawat Inaprsud. Ipteks Terapan. 2017;hal.:75-88.

6. Susanti N, Hartiyah H, Kuntowanto D. Hubungan Berdiri Lama Dengan Keluhan Nyeri Punggung Bawah Miogenik Pada Pekerja Kasir. Di Surakarta; Pena Medika. 2015;hal:60-70.

7. Patrianingrum, M., Oktaliansah, E., \& Surahman, E., 2015; Prevalensi dan Faktor Risiko Nyeri Punggung Bawah di Lingkungan; Jurnal Anestesi Perioperatif, hal. 47-56.

8. Harwanti, S., Aji, B., \& Nur, U., 2016; Pengaruh Posisi Kerja Ergonomi Terhadap Low Back Pain (Lbp) Pada Pekerja Batik Di Kauman Sokaraja. Kesmasindo, hal. 51-58

9. Wulandari, R.A., Maja. P.S.J., Khosama, H, 2013; Gambaran Faktor YangMempengaruhi Nyeri Punggung Bawah Pada Buruh Kapal.

10. Sakinah, S., 2010; Faktor Yang Berhubungan Dengan Keluhan Nyeri Punggung Bawah Pada Pekerja Batu Bata.

11. Safitri A.I., 2010; Hubungan Lama Posisi Duduk Terhadap Nyeri Punggung Bawah Pada Pegawai Rental Komputer di Kentingan Surakarta. Universitas Muhammadiyah Surakarta. Surakarta.

12. Ningsih, W.K., 2017; Keluhan Low Back Pain Pada Perawat Rawat Inaprsud.Ipteks Terapan, hal. 75-88.

13. Susanti, N., Hartiyah, H., \& Kuntowanto, D., 2015; Hubungan Berdiri LamaDengan Keluhan Nyeri Punggung Bawah Miogenik Pada Pekerja Kasir Di Surakarta; Pena Medika, hal. 60-70.

14. Yusuf DR, F I. Hubungan Antara Lama Dan Sikap Duduk Terhadap Kejadian Nyeri Punggung Bawah Di Poliklinik Saraf RSUD Dokter Soedarso Pontianak. IPI Jurnal; 2014.

15. Sari, N. L. N. I., Mogi, I.T., \& Angliadi, E., 2005; Hubungan Lama Duduk Dengan Kejadian Low Back Pain Pada Operator Komputer Perusahaan Travel Di Manado; Jurnal e-Clinic (eCl), hal. 687-694

16. Nur, F.H., Dewi, D.R.L., \& Yanti R.S.A, S.N., 2015; Hubungan Lama Duduk SaatJam Kerja Dan Aktivitas Fisik Dengan Keluhan Nyeri Punggung Bawah; Jurnal Vokasi Kesehatan, hal. 70-74.

17. Samara, D. 2004; Lama dan Sikap Duduk Sebagai Faktor Risiko Terjadinya Nyeri Pinggang Bawah. Vol.23(2).

18. Tarwaka. B, S.H.A. S, L. Ergonomi Untuk Keselamatan Kesehatan Kerja dan Produktivitas. Surakarta: UNIBA press; 2004. 